\title{
Patología Vegetal Micológica
}

\section{Luigi Ciampi, Sergio Radic y Eduardo Alvarez}

La Patología Vegetal representa una importante especialidad de las ciencias agrarias y forestales. Involucra el estudio de todos los aspectos relacionados con los agentes causantes de enfermedades en plantas; quienes las provocan, las formas de penetrar a sus hospederos, que elementos de patogenicidad poseen, y las maneras de prevención y control.

Plantas parásitas, nemátodos, hongos, bacterias, fitoplasmas, virus y viroides conforman un gran conjunto de agentes que de diversas y variadas formas, son capaces de causar severas pérdidas a los cultivos que el hombre utiliza para producir alimentos.

En este vasto conglomerado de agentes, los hongos y microorganismos semejantes a hongos, son el grupo mas numeroso de patógenos que inducen una variada gama de patologias en numerosos cultivos.

Este texto esta dedicado a este grupo particular de agentes infecciosos. En sus páginas se abarcan diversos temas que son de interés para los que se interesan en temas de sanidad vegetal. Se presentan numerosas fichas que ilustran aspectos de síntomas y signos, temas de epidemiología y muchas fotografías en colores. Además, se han incluido esquemas de los signos microscópicos de casi todas las especies que se tratan.

Este texto será de indiscutida utilidad para los alumnos y profesionales se desempeñan en aspectos de sanidad vegetal.

\section{Patología Vegetal Micológica}

Luigi Ciampi, Sergio Radic y Eduardo Alvarez

Instituto de Producción y Sanidad Vegetal

Facultad de Ciencias Agraria

Universidad Austral de Chile

ISBN. 9563104234

266 p., 12 capítulos, tres apéndices y

seis notas complementarias.

Numerosas fotografías a color, esquemas y dibujos.

Formato: 21,5 x $27,4 \mathrm{~cm}$.

Fecha de publicación: diciembre, 2006.

www.iamerica.cl

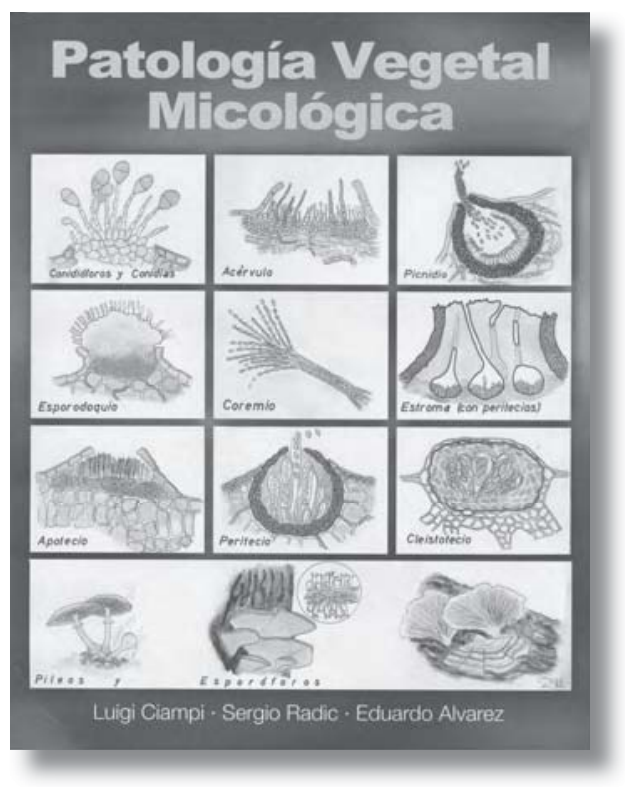

